\title{
OS TEMAS-ENREDOS DAS PEQUENAS ESCOLAS DE SAMBA CARIOCAS
}

Eugênio Araújo

Este artigo corresponde a um capítulo da tese de doutorado Valorizando a batucada: um estudo sobre as escolas de samba cariocas dos grupos de acesso C, D e E, defendida em 2008 e que analisa agremiações pouco conhecidas do grande público, abordando aspectos como história, organização socioadministrativa, inserção no campo carnavalesco carioca, a relação com as grandes escolas do grupo especial e com outras manifestações carnavalescas, além dos itens de desfile, fantasia, alegoria e enredo. Este último aspecto é aprofundado em levantamento percentual entre 2005 e 2008, que alcança corpus de mais de 100 enredos, o que possibilita a identificação de algumas regularidades e características específicas. Uma análise relacional dos enredos das pequenas escolas de sambas tendo o grupo especial como parâmetro - revela discurso peculiar, diferenciado na forma e no conteúdo, mas revela também certa dificuldade de apreensão e apresentação da parte literária do enredo, bem como restrições temáticas que podem estar reforçando as diferenças objetivas e simbólicas entre escolas grandes e pequenas. [abstract on page 280]

\section{CARNAVAL, ESCOLA DE SAMBA, ENREDO.}




\section{HISTÓRICO DA PESQUISA}

Há algum tempo venho estudando as escolas de samba brasileiras, tendo começado em São Luís do Maranhão, minha cidade natal, onde tal manifestação atravessou período francamente desfavorável na década de $1990 .{ }^{1}$ As esco-

1 Trabalho apresentado na 27å Reunião Brasileira de Antropologia, realizada entre os dias $1 \mathrm{e}$ 4 de agosto de 2010, Belém, $P A$. las de samba maranhenses vinham crescendo desde 1950 e chegaram, em finais da década de 1980 , naquilo que se chama comumente de "beco sem saída", devido a dois fatores principais: a adoção do modelo carioca de desfile e o crescimento de novos modelos da festa, como o carnaval baiano. O primeiro levou a sua identificação com uma festa alheia e que por isso não mereceria investimentos dos órgãos de cultura locais, quebrando sua base de sustentação política e econômica; o segundo determinou o afastamento do grande público e da mídia, que preferiram os "novos eventos carnavalescos", geralmente blocos de trio ou de outros tipos regionais. Em 1999 concluí pesquisa de mestrado sobre o assunto (ARAÚJO, 2001) e a partir de então comecei a verificar que o fenômeno se repetia em outras cidades do interior do Maranhão e nas capitais vizinhas. Ao longo de cinco anos, ampliei as observações, tentando captar tal dinâmica em outros locais. Em 2005, para minha pesquisa de doutorado, elegi as pequenas escolas cariocas como objeto de estudo. Tinha muitas dúvidas sobre as formas de fazer e administrar uma escola de samba naquela que é a cidade criadora do folguedo. Assim, dediquei à questão quatro anos de investigação, o que resultou em uma tese de doutorado (ARAÚJO, 2008) e em artigo abordando os processos de criação, evolução e organização desses grupos (ARAÚJO, 2009). A pesquisa procura cobrir as formas de criação e administração, políticas de subvenção, apoio logístico e comunitário, bem como alguns aspectos estéticos da manifestação, como a produção de fantasias, alegorias e enredos. O presente artigo corresponde ao capítulo em que me concentro neste último ponto.

Ao estudar o carnaval maranhense já havia exercitado esse tipo de análise. Em uma cidade em que as escolas de samba passaram a ser consideradas uma espécie de "estrangeirismo", com um discurso "alienado", usei essa estratégia para demonstrar a pertinência do discurso dessas agremiações à realidade local. Uma análise da produção dos enredos das escolas ludovicenses entre 1970 e 1990, a partir dos sambas-enredos de maior sucesso, demonstrou privilégio consciente concedido aos temas locais e regionais. Portanto, a adoção da forma carioca de desfiles não determinou a eleição de conteúdos estranhos à realidade maranhense. Assim, também considerei pertinente verificar sobre o que falavam as pequenas escolas de samba cariocas. Haveria entre elas algum tipo de discurso que as diferenciasse das grandes escolas do grupo especial? Os vários níveis de discrepâncias e peculiaridades formais que eu já observava - no nível dos desfiles, da produção de indumentária e alegórica, etc. - seriam determinados ou determinariam também conteúdos específicos? Assim, dediquei um capítulo da tese ao estudo dos temas-enredo; e digo "temas-enredo" porque o estudo do enredo pode ser feito de forma mais particularizada ou mais abrangente. Um estudo mais particularizado vai-se preocu- 
par com a produção de um carnavalesco ou de uma escola de samba ao longo do tempo, procurando captar linhas lógicas de raciocínio ou proposição de uma produção particular. Como veremos adiante, isso já foi feito por Cavalcanti, em relação ao Salgueiro e seus enredos de "negritude" da década de 1960, ou ainda por Cunha Junior (2006), quanto à produção do carnavalesco Joãozinho Trinta.

Meu objetivo, no entanto foi outro: pretendia tentar captar sinais de um discurso diferenciado do conjunto das escolas cariocas dos grupos de acesso; não apenas de uma delas, nem de um artista que nelas atuasse - algo que se aproximasse, talvez, de um discurso coletivo, dado pela repetição, pela insistência e pela recorrência a determinados temas-enredos. Consequentemente não recorri aos expedientes clássicos de uma "análise de discurso" - com identificação de termos significantes, classificação em grupos e subgrupos de palavras referentes a este ou aquele significado, e o levantamento criterioso do número de vezes que tais termos são citados, etc. ${ }^{2}$ Meu objetivo é mais simples: apenas verificar o grau de recorrência a determinados temas, identificá-los e a partir daí sugerir interpretações possíveis, com base na verificação do material escrito e no discurso dos agentes produtores, os próprios carnavalescos e diretores de escolas de samba. Através desse expediente é possível identificar preferências sobre determinadas questões, bem como a forma como são tratados e desenvolvidas.

Esta análise fundamenta-se no estudo de 109 enredos do universo de 143 enredos apresentados entre 2005 e 2008, o que perfaz cerca de $70 \%$ do total. Embora haja certo desequilíbrio nas amostras anuais - são apenas nove enredos de 2005 contra o total apresentado em 2007 e 2008 -, creio que a amostra geral seja suficiente para a identificação de características e tendências, no nível da forma e do conteúdo.

\section{O ENREDO, SUAS PARTES E SEU SIGNIFICADO}

Começo, então, por esta diferenciação básica, entre tema e enredo:

Tema é o assunto geral. Enredo é o subtema que será enfocado entre as possibilidades existentes. $O$ enredo é delimitação de um tema maior. $O$ enredo é a proposição de realidade ficcional, descritiva ou até mesmo

2 Bom exemplo disso temos em Augras, 1998. A autora analisa detalhadamente várias letras de sambas-enredo, recorrendo ao método clássico da análise de discurso, identificando mensagens denotadas e conotadas, mapeando tendências, traçando uma história desse gênero musical no Brasil. No geral, o estudo dos enredos implica também o dos sambas-enredo. No entanto, aqui tentarei verificar como isso se dá entre as escolas dos grupos de acesso $C, D$ e $E$ do carnaval carioca, exclusivamente a partir de seus temas-enredo.

3 Baseado em definições de Samira Mesquita, Darcília Simões, Fernando Pamplona e Clécio Mesquita. dissertativa que constitui o fio condutor de um desfile de escola de samba. É a concepção de base que estrutura toda realização semiológica do espetáculo - categoria do gênero épico, é o elemento de controle maior sobre o processo de leitura do desfile. O enredo não é apenas o tema em si, mas principalmente a maneira como foi tratado, em função do samba e do desfile. A criação do enredo obedece a dois momentos distintos: o literário e o plástico visual (FARIAS, 2007, p. 15-16). ${ }^{3}$ 
A importância do enredo, "esse gênero novo que inventou seus próprios cânones e módulos" (RIOTUR, 1991, p. 309), tem sido observada por vários estudiosos. Aceitando, como DaMatta (1990, p. 55), "que os ritos dramáticos expressam uma maneira diferente de perceber, interpretar e representar aquilo que se deseja construir como realidade social brasileira e dizem algo sobre a estrutura social", é possível ver enredos e sambas-enredos como discursos das escolas, um tipo de "pensamento social", como prefere Cavalcanti (1999, p. 27), responsável pela afirmação ou negação de algumas ideias.

A ideia de argumento, como elemento fundador do enredo, já se encontra no livro Memória do Carnaval (RIOTUR, 1991, p. 309), uma tentativa de sistematização mais completa dos processos de trabalho desenvolvidos nas escolas de samba:

As escolas elaboram um documento, uma narrativa que transcende a história contida no enredo, o script ou texto. E como complemento, o roteiro ou ordem de desfile, que é o desenvolvimento daquele texto pelas alas, destaques, alegorias e adereços. Tal documento chama-se argumento.

Segundo Farias (2007, p. 41), a ideia de "argumento" é o que parece orientar a feitura e apresentação de enredos no grupo especial:

O argumento, segundo o Manual do Julgador é o texto escrito que a escola de samba apresenta aos jurados. Esse texto sobre o enredo subdivide-se em "histórico do enredo" e "justificativa do enredo". São textos complementares; o primeiro explicará o tema proposto e o segundo defenderá sua relevância cultural.

Outros autores sublinham o processo pedagógico através do qual se produzem enredo, samba-enredo e desfile:

O enredo possibilita oportunidade de aprendizado única para alguns componentes, pode-se dizer que são verdadeiros "temas geradores" para o processo de conhecimento das classes populares organizadas em torno da escola de samba. $O$ educador Paulo Freire analisou profundamente o papel dos "temas geradores" nos processos de aprendizado. Segundo ele, a partir da situação presente, existencial do educando, pode-se organizar um conteúdo programático da educação. A execução do enredo também desenvolve noções de dramaturgia: construção de personagens, cenários e ambientações (TRAMONTE, 2001, p. 134).

Parto agora para uma análise dos dois aspectos sob os quais o enredo pode ser apreendido, forma e conteúdo, uma parte correspondendo a sua apresentação escrita (no nível do significante), e outra àquilo a que se refere e remete (no nível do significado).

\section{APRESENTAÇÃO FORMAL DOS ENREDOS}

Objetivamente, enredo é uma peça literária, uma descrição ou prospecção escrita daquilo que a escola mostrará na avenida. Nesse ponto há certa tensão com aquilo comumente identificado com "linguagem carnavalesca", de caráter geralmente libertário e subversivo - a parte escrita do enredo é preparada para orientar o corpo do júri e deve primar pela clareza, explicando aspectos possivelmente obscuros da apresentação 
da escola em desfile, explicitando relações esboçadas na avenida, orientando a leitura da apresentação - o enredo é um libreto explicativo. Assim, o carnavalesco dado a voos imaginativos e imprevisíveis quando trata com seus meios privilegiados de expressão (as artes visuais), deve esforçar-se para, na contraparte escrita do enredo, elucidar e justificar objetivamente todos os pontos a serem desenvolvidos no desfile. Alguns carnavalescos das escolas observadas declararam não ter muita intimidade com o processo de pesquisa e formatação escrita do enredo, delegando a tarefa a terceiros - geralmente estudantes universitários e/ou professores de história, geografia e outras ciências humanas, com mais domínio da língua escrita. Essa função pode ser exercida por comunitários e simpatizantes da agremiação ou por profissionais contratados especialmente para isso.

No tocante à forma, o material que me foi repassado pela Associação das Escolas de Samba da Cidade do Rio de Janeiro - AESCRJ apresenta grande variação. Parece ainda não haver forma padronizada de apresentação da parte literária dos enredos entre as escolas dos grupos de acesso, a exemplo do que acontece no grupo especial: a Liesa publica anualmente e repassa aos jurados a revista Abre-Alas, da qual constam todos os enredos das escolas concorrentes, apresentados de forma-padrão. ${ }^{4}$

O Regulamento da AESCRJ (2005, p.8) exige das escolas, como "obrigação", a apresentação de um "script do enredo e letra do samba-enredo, bem como a ficha técnica da agremiação" . O Regulamento também alerta para a "necessidade de entregar à AESCRJ um histórico e justificativa do enredo, o roteiro do desfile (descrição sequencial das alas, alegorias e outros elementos constituintes do seu desfile) e outros que julgar necessários..." (AESCRJ, 2005, p. 9). No entanto, o termo script - o primeiro usado ao tratar do quesito enredo - tem sido interpretado com muita liberdade pelos carnavalescos e diretores.

Dos 109 enredos pesquisados, 107 apresentam histórico, 89 incluem o roteiro, mas apenas 46 oferecem justificativa, que geralmente não ultrapassa um parágrafo. Apenas uma minoria apresenta um script completo, que inclui o histórico, justificativa, roteiro de desfile mais a letra do samba-enredo e ficha técnica. A maioria fornece apenas algumas dessas partes, em geral o histórico ou o roteiro, o que acaba por determinar o caráter heterogêneo do material. Além disso, é grande a variação da terminologia utilizada na identificação, bem como a ordem de apresentação; assim, a justificativa nem sempre vem no início e pode constar como "introdução, apresentação, objetivo, editorial, defesa de enredo ou prólogo"; o histórico também recebe os nomes de "explicativa, apresentação, sinopse ou pesquisa de enredo"; e o roteiro pode figurar como "organograma, cronograma, desfile, programa de desfile, ordem de desfile ou armação da es-

4 São publicados dois volumes por ano, um para cada dia de desfile. A forma-padrão de apresentação inclui: 1 - Ficha Técnica do Enredo londe constam autores e bibliografia); 2 - Histórico do Enredo; 3 - Justificativa do Enredo; 4 - Roteiro de Desfile; 5 - Ficha Técnica das Alegorias; 6 - Ficha Técnica das Fantasias; 7 - Ficha Técnica do Samba-enredo; 8 - Ficha Técnica da Bateria; 9 - Ficha Técnica da Harmonia; 10 - Ficha Técnica da Evolução; 11 - Ficha Técnica do Conjunto; 12 - Ficha Técnica da Comissão de Frente; 13 - Ficha Técnica do Mestre-Sala e Porta-Bandeira (LIESA, 2005).

5 Título II, art. 22, item IX - Das obrigações das escolas de samba e demais recomendações. 
cola". Essa variação terminológica torna difícil até mesmo a identificação das partes que compõem o enredo. Observa-se assim considerável defasagem no nível formal dos enredos pesquisados, inclusive no tamanho: há aqueles apresentados em apenas uma lauda, sem qualquer informação adicional que facilite a compreensão do "tema gerador" e seu desenvolvimento, enquanto outros chegam a mais de 20 páginas, incluindo algumas vezes esboços e esquemas visuais de alegorias e fantasias. Todos esses fatores podem influenciar decididamente a avaliação do quesito, onde também as discrepâncias se tornam visíveis - pois o Manual do julgador das escolas dos grupos de acesso indica que o jurado deve considerar no quesito enredo o seu "argumento, roteiro e desenvolvimento" (AESCRJ, 2003, p. 25) e a "relação entre tema ou conceito proposto e que está sendo apresentado na avenida" (AESCRJ, 2008, p. 29). Não há neste Manual qualquer menção a um script, expressão que consta do Regulamento repassado aos agentes produtores. Assim, as variações terminológicas e um desencontro entre o exigido e o realmente apresentado podem estar prejudicando a performance das escolas dos grupos de acesso. A grande diversidade formal dos enredos das escolas dos grupos de acesso C, D e E pode ser resultado da falta de esclarecimento dos elementos que constituem um enredo e da relação entre eles. Alguns enredos baseados em temas e ideias incomuns acabam não se realizando na totalidade, o que afeta diretamente o conteúdo e tem seus efeitos na realização plástico-visual, a culminância do processo. Assim, o pouco domínio técnico na produção da parte textual dos enredos confirma a distância entre os grupos de acesso e o grupo especial, como veremos adiante.

\section{SOBRE O QUE FALAM OS ENREDOS DAS PEQUENAS ESCOLAS CARIOCAS?}

Em relação ao conteúdo propriamente dito, Farias (2007, p. 48) estabelece uma tipologia dos enredos realizados pelas escolas do grupo especial:

Os temas dos enredos são muito variados. Podemos distinguir pelo menos os seguintes tipos: histórico, literário, folclórico, homenagem à personalidade/ biográfico, metalinguístico, geográfico, de crítica social, de humor, abstrato ou conceitual, sobre objetos, esportivo, de temática infantil, de temática afro-brasileira, de temática indígena e de patrocínio. Sendo que vários enredos podem se inserir em mais de uma categoria.

Considerando essa classificação, é possível encaixar os enredos das escolas dos grupos de acesso C, D e E entre 2005 e 2008, em quadro percentual de acordo com a frequência (Tabela 1).

Observa-se a predominância de dois tipos de enredo, homenagem a personalidades e de temática afro-brasileira, que, juntos, representam 35,1\% do total. Há, porém, um dado complicador: dos 22 enredos computados como homenagem a personalidades, 17 são dedicados a personagens negros, possibilitando sua inclusão na categoria temática afro-brasileira, somando 34 enredos (aproximadamente $30 \%$ do total). Nesse sentido, o que foi separado inicialmente a bem da clareza numérica e percentual pode sustentar outras leituras. Há outros casos: um enredo-homenagem sobre o artista plástico Caribé, 
que apesar de ser branco e argentino trabalhou especificamente com a estética afro-brasileira; um sobre Angola, computado como geográfico, pode também ser deslocado; outro sobre instrumentos de percussão, alocado na categoria arte, e mais quatro enredos de autolouvação (auto-homenagem, geralmente por ocasião do aniversário das escolas) podem, se somados aos 17 enredos inicialmente computados como temática afro, elevar esse número para 41 - o que deixaria os enredos afro com quase a metade de tudo que foi apresentado entre 2005 e 2008 - isso sem considerar a "reverberação afro" em outros enredos como veremos adiante.

\begin{tabular}{|l|l|l|}
\hline TIPO DE ENREDO & QUANTIDADE & $\%$ \\
\hline Homenagem a personalidades & 22 & 20,1 \\
\hline História e mitologia afro-brasileira & 17 & 15 \\
\hline Festas (folclore) & 12 & 11 \\
\hline História do Brasil/louvação ao Brasil & 12 & 11 \\
\hline Místico/abstrato/conceitual & 10 & 9 \\
\hline Geográfico (lugar, bairro, cidade, país - exceto Brasil) & 8 & 7 \\
\hline Ecológico & 8 & 7 \\
\hline Arte & 5 & 4,5 \\
\hline Objetos & 3 & 4,5 \\
\hline Autolouvação & 4 & 3,6 \\
\hline Institucional & 3 & 2,6 \\
\hline Crítica Social & 3 & 2,6 \\
\hline Cotidiano & 2 & 2,1 \\
\hline TOTAL & $\mathbf{1 0 9}$ & $\mathbf{1 0 0}$ \\
\hline Tabela 1: Frequência de temas-enredo entre $\mathbf{2 0 0 5}$ e $\mathbf{2 0 0 8}$ & \\
\hline
\end{tabular}

Depois dos enredos de temática afro-brasileira, que configuram isoladamente a maioria, há um grupo de cinco categorias cantadas de oito a 12 vezes entre 2005 e 2008: a terceira e quarta categorias mais citadas - fechando o grupo dos enredos que tiveram dez ou mais citações em quatro anos - são as das festas, da história ou louvação do Brasil e as do tipo místicos/abstratos/conceituais (geralmente ideias originais desenvolvidas pelos carnavalescos); juntos eles perfazem 31\% do total. Depois vêm os enredos geográficos e ecológicos. Nos enredos históricos, sobre festas e geográficos $(29 \%)$ há ainda muita reverberação da temática afro-brasileira, posto que a maioria das festas lembradas possui forte identificação com as tradições negras (reisados, congadas, maracatu, carnaval); muitos dos episódios históricos têm a participação efetiva dos negros escravos, e a louvação ao país quase sempre descamba para autolouvação (ao samba, ao carnaval, ao futebol como identificadores da cultura brasileira, em que a participação da etnia negra sobressai); e ainda muitos dos lugares homenageados são bairros caracterizados pela maioria negra da população (Madureira, Méier, Morro do Alemão, São João do Meriti, Santa Cruz). Sendo assim, percebe-se ainda influência difusa da temática afro nesses enredos - o que aumenta ainda mais sua influência, não obstante deixar o desfile por vezes um tanto repetitivo. Mais diferenciados são os dos tipos ecológico e conceitual, que comparecem 18 vezes e traduzem outras preocupações: a questão da preservação da natureza, muito em voga atualmente, e uma tendência de evasão mais livre e onírica. No primeiro grupo constam enredos sobre a reciclagem de lixo, a poluição das águas, a flores- 
6 Essa visão é confirmada por Farias (2007, p. 76):

"O enredo de temática afro-brasileira expandiuse na década de 1960, quando o Salgueiro começou a exaltar o negro, evidenciando "vultos negros silenciados pela oficialidade". É uma das temáticas preferidas do carnaval, não só pelas possibilidades de sua constituição plástica, mas porque retoma as origens de uma raça, precursora do samba e do próprio carnaval brasileiro."

7 "Em 1960, o samba do enredo Zumbi dos Palmares canta o quilombo e seu herói negro. Os escravos aqui são revoltosos que fogem da opressão e do jugo dos portugueses. Buscam no quilombo, a paz e a liberdade (...) Em 1963, o samba do enredo Chica da Silva canta outro tipo de heroísmo, mais próximo da malandragem, pois que não opera pelo conflito aberto... a arma de combate é a sensualidade. $A$ mulata, a escrava que foi comprada pelo contratador... a influência e o poder seu amor vence a barreira da cor (...) Chico Rei é o herói de uma integração efetiva a um sistema que equilibra a malandragem e o trabalho, a causa individual e a causa coletiva. Chico que era rei na África, indo trabalhar nas Minas Gerais tem a ideia de esconder o ouro em pó ta amazônica, o café, a "mãe terra" e o sol; no segundo, sobre ditos populares, lendas urbanas, o zoodíaco, sobre partes do corpo (no caso, o pé), a internet, luta entre o bem e o mal - configuram, sem dúvida o grupo mais incomum de enredos entre os pesquisados.

Depois dessas categorias intermediárias, há aqueles tipos de enredos pouco cantados, como os que versam sobre mitologia ameríndia (apenas dois enredos sobre lendas indígenas), três que fazem crítica social mais contundente (sobre a paz e a corrupção) e três que se encaixam na linha chamada "institucional", geralmente patrocinados por empresa privada ou órgão público (Universidade do Samba Estácio de Sá, Projeto Bairro Escola/Prefeitura de Nova Iguaçu, Museu Nacional/UFRJ), insinuando timidamente, em meio aos grupos de acesso, uma tendência já dominante no grupo especial. Os enredos críticos estão em baixa mesmo no grupo especial - ao qual, nos anos 80 , conferiram especial colorido -, o que mais uma vez pode indicar as dificuldades de manutenção do folguedo. Geralmente só se assume a visão crítica quando há garantia de certa tranquilidade e a simpatia pela manifestação, o que impediria possíveis retaliações. Não é o que acontece hoje com as escolas de samba, que parecem estar na corda bamba, sempre em busca de desfilantes, público e financiamento - a estratégia dos enredos de encomenda, com tendência para o marketing de viagens (enredos sobre cidades e localidades turísticas, os chamados enredo "cartão-postal") ou sobre amenidades, parecem contemplar esse aspecto, demonstrando que o momento é de angariar adeptos e investidores, mesmo sacrificando um discurso original e com potencial crítico mais ácido.

Dessa forma, vê-se nítida predominância da temática afro-brasileira no conjunto de enredos apresentados pelas escolas dos grupos de acesso C, D e E, no período pesquisado. Por isso os analisaremos mais detalhadamente.

\section{A TEMÁTICA DA NEGRITUDE NAS ESCOLAS DE SAMBA CARIOCAS}

Os estudos sobre as escolas de samba já identificaram a gênese dessa tendência temática na década de 1960, coincidindo com outros processos determinantes na evolução das escolas de samba cariocas: a aproximação de artistas plásticos de formação acadêmica com a consequente primazia do visual, a "in- 
vasão" das classes médias, o incremento da comercialização. Pode-se dizer que a invenção da "temática racial" no carnaval das escolas de samba não é iniciativa "popular", dos negros que sustentavam o movimento sambista, mas de um grupo de intelectuais que resolve colaborar com as escolas de samba. Esse processo de invenção ou construção de nova tradição temática já foi observado por Cavalcanti (1999, p. 27, 30, 34), em artigo especialmente dedicado a essa discussão:

Por temática racial, entendo o conjunto de questões ideológicas suscitadas pelo fato histórico da escravidão e seu lugar no processo de constituição do Brasil como nação. A atuação dos carnavalescos no Salgueiro com seu impacto temático e estético é uma das referências da história recente do carnaval. O grupo do qual fizeram parte, entre outros, Fernando Pamplona, Arlindo Rodrigues, Rosa Magalhães e Maria Augusta, uma vez desfeito se espalhou pelas demais escolas, imprimindo sua marca nos rumos do carnaval das décadas seguintes. Com esse grupo de carnavalescos o Salgueiro trouxe, em 1960, o enredo Quilombo dos Palmares; em 1963, o enredo Chica da Silva; em 1964, Chico Rei; em 1969, Bahia de todos os deuses; e em 1971, Festa para um Rei Negro ou "Pega no ganzê". 6

A autora destaca quatro enredos - Quilombo dos Palmares, Chica da Silva, Chico Rei e Festa para um Rei Negro - traçando uma linha de leitura estético-social. A temática racial colocaria algumas possibilidades de abordagem e resolução distintas: o conflito aberto de Zumbi, a sedução individual de Chica da Silva, o trabalho metódico e coletivo liderado por Chico Rei e a possibilidade da integração pela festa do último exemplo. Cada enredo afirmaria uma dessas possibilidades, forjando uma espécie de "cânone da temática racial" no carnaval brasileiro. Segundo Cavalcanti (1999, p. 36), "elaborando mitos ligados à escravidão no Brasil, os enredos parecem estabelecer entre si uma conversa". ${ }^{7}$

A reverberação desses enredos nos anos seguintes por todas as escolas é chamada de "efeito Salgueiro" por Augras (1998, p. 93), relevando a "preponderância da dimensão imaginária", em que a "África toma feições de grande mãe mítica dos sonhos populares". Depois do momento fundador, Cavalcanti (1999, p. 39) identifica período no qual a temática afro foi subaproveitada: "entre 1971 e 1988 a temática racial reverbera enfraquecida (...) predomina a ideia da integração do negro ex-escravo à sociedade nacional através de suas manifestações culturais e da Bahia, cantada enquanto sede da 'tradição nagô', símbolo máximo dessa cultura." ${ }^{8}$ Ela voltará com força em 1988, por ocasião da comemoração dos 100 anos da abolição da escravatura. Mais uma vez, a autora identifica quatro possibilidades distintas de discurso sobre o fato histórico: 
9 "A Tradição homenageava "este Brasil miscigenado" com o enredo $\mathrm{O}$ melhor da raça, o melhor do carnaval. Seu objetivo era mostrar que nosso povo reúne em si o meIhor de cada uma das etnias formadoras da nação brasileira. A mistura das três raças apresenta a "Tradição da cor brasileira" (...) A Beija-Flor trouxe o enredo Sou negro do Egito à Liberdade. Apoiado na egiptologia moderna, mostrava o negro na origem de grande civilizações, mostrando a continuidade entre a cultura egípcia, a africana e a nossa. O samba-enredo, contudo, enfatizava a escravidão (...) A Vila Isabel trouxe Kizomba, a festa de uma raça (...) reafirmação de Zumbi dos Palmares como símbolo da liberdade do Brasil. Informa-se sobre líderes revolucionários e pacifistas de outros países, protestase contra a discriminação racial no Brasil e manifesta-se contra o apartheid na África do Sul... ao mesmo tempo em que a $\mathrm{Ki}$ zomba é uma festa. (...) Finalmente a Mangueira falava da escravidão, da força da influência da tradição negra na cultura brasileira e questionava a abolição com o enredo 1988, Lei Áurea: Cem anos de liberdade ou de discriminação" (CAVALCANTI, 1999, p. 42).
A comemoração do centenário da abolição repunha explicitamente a polaridade central da temática racial. A Tradição homenageou "este Brasil miscigenado"; a Beija-Flor proclamou "liberdades maiores do negro"; a Vila conclamou para a festa de uma raça; a Mangueira denunciou a "ilusão da abolição". Ao fazê-lo, lançaram mão de possibilidades distintas de mediação da oposição: a integração/ harmonia versus resistência/conflito (CAVALCANTI, 1999, p. 42$).^{9}$

Assim se fecha mais um ciclo canônico para os enredos de temática afro-brasileira no carnaval carioca. Tentarei agora uma verificação da influência desses cânones nas escolas dos grupos de acesso C, D e E.

Dos 41 enredos finalmente computados como do tipo afro-brasileiro - incluindo as homenagens, os geográficos e artísticos - teremos a predominância (17) das homenagens a personalidades negras (muitas delas ainda vivas), o que realça a percepção da contribuição de caráter pessoal dessas personagens, indicando consciência social cada vez mais determinada pelo individualismo. Desses 17, a maioria é de sambistas: tia Ciata, tia Doca da Portela, tia Alice da Mangueira, Natal da Portela, Manoel Dionísio (da escolinha de mestre-salas e porta-bandeiras), Zé Ketti, Mano Décio da Viola, Ivo Meirelles, Grupo de Pagode Pique Novo, Cartola e Xangô da Mangueira. Mas há também um jogador de futebol (Rildo Menezes), um jornalista (Fernando Moreno), uma escritora e ativista do movimento negro (Thereza Santos) e um gari (Renato Sorriso, que se tornou conhecido por sambar, na Marquês de Sapucaí, varrendo a pista depois da passagem de cada escola). Vale dizer que se trata, em sua maioria, de artistas ou pessoas comuns, que tiveram suas trajetórias aproximadas pela identificação com signos de negritude (samba, escola de samba, movimento negro, etc.) e por isso mereceram a homenagem. Não são heróis míticos no sentido de Zumbi, Chica da Silva ou Chico Rei.

Seguem-se os enredos que versam sobre a mitologia afro-brasileira, com especial ênfase nos aspectos religiosos. São seis enredos que se concentram sobretudo, nas lendas sobre deuses africanos e afro-brasileiros, demonstrando a força dos relatos mítico-religiosos. ${ }^{10}$ Essa tendência foi observada por Cavalcanti no período entre 1971 e 1988, quando era comum a referência às tradições religiosas nagô. Logo em seguida vêm os enredos do tipo histórico, com ênfase nos relatos de lutas e con- 
flitos pela liberdade. São cinco enredos, três deles dedicados a movimentos quilombolas, provando que o mito do "herói mártir" Zumbi, continua operante. ${ }^{11}$ Há, no entanto, um enredo que se diferencia por tratar especificamente do período "pós-abolição" (Unidios de Cosmos, 2007), efetuando recorte histórico que Ihe possibilita abordar aspectos contemporâneos da questão.

Três enredos homenageiam uma África genérica, enquanto continente originário de várias civilizações e das etnias negras deportadas para o Brasil - tendência observada por Cavalcanti em 1988 - mas há dois enredos diferenciados por investigarem apenas um país, demonstrando a consciência da diversidade presente no grande continente africano, com suas muitas etnias e dialetos - tipo de enredo raro até hoje, mesmo no grupo especial, mas que parece ter relação direta com o Kizomba da Vila Isabel (1988), que já fazia referência a países e líderes estrangeiros de forma bem marcada (Luther King nos EUA, Mandela na África do Sul). ${ }^{12}$

\section{O JULGAMENTO DOS ENREDOS}

Considerando a avaliação desses enredos pelo júri, é possível suscitar outras discussões. Nos quatro anos de observação, apenas 18 enredos mereceram a nota máxima do corpo de jurados (duas notas dez, somando 20 pontos), assim como coincidentemente, 18 enredos foram mal avaliados (somando menos de 18 pontos ${ }^{13}$ ). Surpreendente equilíbrio entre o considerado excelente e o insuficiente. No entanto, dos 18 enredos bem avaliados pelo júri, apenas 11 se enquadram na categoria "completo", do aspecto formal já aludido, isto é, que inclui um suposto "argumento" dividido em histórico, justificativa e roteiro (mesmo que apareçam com outra terminologia). Os demais sete, decididamente não apresentam todas as partes, havendo mesmo, entre eles, aqueles de uma lauda só. Da mesma forma, dos 18 enredos mal avaliados pelo júri, novamente 11 são incompletos, enquanto os outros sete apresentam todas as partes, configurando o que chamei de "enredo completo", do ponto de vista formal.

Se a análise considerar o conteúdo, igual equilíbrio é observado, pois entre esses 36 enredos (18 ótimos e 18 ruins) há os de todas as temáticas, com leve preponderância, entre os 18 melhores, para os do tipo homenagem e afro-brasileiro - que somam seis enredos com nota máxima, sem dúvida devido à fre-
10 Obá, a terceira mulher de Xangô (Rosa de Ouro, 2005), A festa dos deuses afro-brasileiros (Em Cima da Hora, 2006), Olodumarê: das profundezas ao sopro da vida (Amarelinho, 2008); Itan: a saga dos guerreiros da terra (Vigário Geral, 2008); A viagem fantástica de Ogum ao inebriante universo da cerveja (Imperial de Morro Agudo, 2008); Yeye Omon Ejá e a fé que deságua no mar (Delírio da Zona Oeste, 2008).

11 Os afrodescendentes constroem o Brasil (Acadêmicos do Dendê, 2006), Gamga Zumba, raiz da liberdade (Acadêmicos do Engenho da Rainha, 2007), Curukango (Vila Rica, 2007), Sou Cosmos, 100\% negro: da Abolição aos dias atuais (Unidos de Cosmos, 2007); O sonho não vai sucumbir, sou da Costa do Sol, herança de Zumbi (Flor da Mina do Andaraí, 2008).

12 Do primeiro tipo: Jacarezinho guerreiro mostra que a África é aqui (Unidos do Jacarezinho, 2006); África, berço das civilizações (Unidos do Anil, 2007); De braços abertos o Engenho embala a África em berço esplêndido (Engenho da Rainha, 2008). Do segundo tipo: Dudu Alabunkun do Arrastão visita a terra dos Yorubás (Villa Rica, 2206, sobre a Nigéria) $e$ Angola: na saga da rai- 
nha a dignidade de uma nação (Unidos do Cabral, 2008).

130 Manual do Júri determina que as notas atribuídas aos quesitos podem ir de sete a dez, passando por todas as casas decimais (7.1, 7.2, 7.3 e assim sucessivamente). Como são dois jurados por quesito, em cada um deles a menor nota que uma escola pode obter será 14, isso se os dois conferirem a nota mínima. Como observei que a nota sete é usada muito criteriosamente, sendo os decimais de nove e oito muito mais frequentes, decidi considerar "mal avaliados" enredos que obtivessem nota inferior a 18 pontos, o que significa que os dois jurados conferiram nota inferior a nove.

14 "O julgamento deve refletir uma análise técnica com base nas questões inerentes a cada quesito, levando-se em conta, única e exclusivamente, $o$ real desempenho e a qualidade do que for apresentado, por cada escola no momento do desfile, enfatizamos, em cada quesito. É fundamental que cada julgador se atenha apenas ao quesito para o qual foi incumbido analisar" (AESCRJ, 2008, cap. Orientações sobre julgamento, item 5 - Sistema de concessão de notas, p. 15). Também no item referente ao julga- quência com que são reeditados; e entre os 18 piores, para os de temática geográfica (que somam quatro enredos mal avaliados sobre localidades, principalmente bairros - quando o total dessa modalidade chega apenas a oito enredos, o que significa que a metade da produção total sobre essa temática foi considerada fraca nos últimos anos).

Assim, se é possível identificar preferências temáticas no quesito enredo por partes dos agentes produtores, é impossível identificar preferências do júri por esta ou aquela temática. Porém, assim como foram identificadas algumas dificuldades na formatação e apresentação da parte literária do enredo por parte das escolas, também é visível certa dificuldade de avaliação do enredo, por parte do júri, como peça independente, que vale por si, livre das influências de outros quesitos de julgamento, especialmente aqueles avaliados durante o desfile, como os que apelam para o visual e conjunto - o que é proibido pelo $\mathrm{Ma}$ nual do Julgador, que recomenda a cada jurado importar-se apenas com o que diz respeito a seu quesito, ignorando falhas e excelências em outros pontos da escola. ${ }^{14}$ Acontece que o júri do quesito "enredo" recebe com antecendência o material para avaliação, assim como também eu, o pesquisador, os recebia quase uma semana antes do desfile, para estudo prévio. Em se tratando de enredo laudatório - como há alguns - é impossível efetuar a leitura na hora do desfile. Assim, o julgamento do enredo pode ser feito de maneira completamente independente; por sua configuração literária ele tem existência e critérios de julgamentos propriamente literários. O que se identifica é a "contaminação" da nota do enredo pela performance apresentada pela escola em desfile.

\section{ENREDOS ESPECIAIS X ENREDOS DE ACESSO}

Como adiantei, minha análise das escolas cariocas dos grupos de acesso é relacional, procurando sempre manter em vista o grupo especial, como uma espécie de grupo-controle, modelo e padrão, já que as escolas estão organizadas hierarquicamente em ordem crescente rumo ao grupo especial; para chegar até ele é preciso adotar seu éthos, hábitos e maneiras "especiais", que incluem o quesito enredo.

O desfile do grupo especial é uma festa cheia de códigos (denotados e conotados) que devem ser apreendidos. Não basta estar elegantemente vestida e fazer um desfile correto; é pre- 
ciso dominar uma série de truques e traquejos sociais, cuja aquisição pode representar significativa dificuldade para as escolas emergentes. São regras e normas objetivas ou subjacentes e subentendidas, comparáveis a um complexo manual técnico, por um lado, e de etiqueta, por outro, definindo aquilo que se chama "escola de elite" ou "grupo de elite do carnaval carioca". ${ }^{15}$ Nesse sentido, a subida para o grupo especial seria uma etapa de rito de passagem, incluído num processo civilizador mais geral, no sentido eliasiano (ELIAS, 1994). ${ }^{16}$ Chegar lá significa ter deixado para trás uma série de mazelas, cacoetes, manias e hábitos que denunciavam a falta de refinamento, associadas à origem inferior.

A participação satisfatória no desfile do grupo especial requer aprofundamentos sofisticados nos vários itens que compõem o regulamento, desde a pesquisa do enredo (que deve ser "original") a seu desenvolvimento, roteiro, desenho e projetos de fantasias e alegorias e a contratação de inúmeros técnicos e artesãos especializados. No caso de um enredo "hermético", o domínio conceitual cabe somente ao carnavalesco, profissional polivalente que atua em diversas frentes do processo de criação, produção, mediação e performance artística. Em tradição iniciada entre as décadas de 1960 e 1970, por Fernando Pamplona, João Trinta e Arlindo Rodrigues, ele não desempenha apenas o papel de artista plástico, mas assume ainda funções de pesquisador, escritor, diretor de espetáculo e relações públicas - e, mais recentemente, de agente captador de recursos (a partir de um "enredo patrocinável").

Assim, os enredos do grupo especial passaram por um processo de sofisticação que trouxe novas exigências, só preenchidas por profissionais com formação adequada, frequentemente acadêmica - imbricam-se aqui o capital cultural do artista com o da escola. Assim, "um bom carnavalesco custa caro", já que pode garantir a nota máxima em pelo menos três quesitos (enredo, fantasia e alegoria). A formação do carnavalesco, suas relações com a sociedade mais ampla e seus critérios de pesquisa refletem-se diretamente na escolha e desenvolvimento do enredo, na concepção de fantasias e alegorias - tudo isso perfaz o "capital simbólico do Grupo Especial", no sentido de Bourdieu (1995, 1996), traços honoríficos que preveem e geram acúmulos de privilégios, e, ultrapassando o "luxo" imediato, se afirmam como barreira simbólica quase intransponível para as escolas menores. No quesito enredo, desde a década de 1960, a Sapucaí tem sido palco de verdadeiras demonstrações de virtuoses de pesquisa histórica, reconstruções de época mento do "Quesito Enredo", o manual recomenda "não levar em consideração questões inerentes a quaisquer outros quesitos" (p. 20).

15 Sobre o estudo dos grupos de elite e seus processos de diferenciação e manutenção de status ver BOTTOMORE, $1974 \mathrm{e}$ TURNER, 1989.

16 Ver especialmente $o$ capítulo 2, A civilização como transformação do comportamento humano. Em outro período, Cunha (2001, p. 99) também interpreta a luta entre grandes sociedades $e$ entrudo, em termos "civilizatórios": "As sociedades carnavalescas aparecem na segunda metade do século XIX anunciando que a civilização atingira o domínio de Momo. Marcaram época e constituem o mais importante capítulo dessa história de relações perigosas entre os poderes constituídos e as chamadas 'classes populares' e as elites intelectuais e políticas em torno daquilo que era normalmente designado como os dias de folia." 
(tanto em cenografia quanto em indumentária), tudo isso baseado em prospectos escritos que flertam abertamente com o mundo da pesquisa acadêmica ${ }^{17}$ - o mundo letrado, da língua escrita, do capital escolar e universitário.

Percebi ainda através dos discursos dos carnavalescos e diretores, uma diferenciação entre determinados temas-enredos, considerados mais adequados para uma escola, dependendo da posição em que ela se encontra: se está no grupo especial, nos grupos de acesso A e B (que desfilam na Sapucaí) ou nos grupos de acesso C, D e E (que desfilam na Intendente Magalhães, em Campinho). Vimos que os enredos tipo homenagem a personalidades negras conferem certa originalidade ao discurso das escolas dos grupos de acesso C, D e E; a outra parte dos enredos de temática afro-brasileira pode ser considerada - com algumas ressalvas - reverberações daqueles identificados por Cavalcanti como fundadores dos ciclos de temática racial no carnaval carioca. Mas, além do desejo do reconhecimento individual, do arraigamento religioso e da democratização da história afro-brasileira, a preferência pelos enredos afro pode ter motivos mais prosaicos, como lembra um ex-carnavalesco:

17 Eis alguns exemplos: "Fritoj Capra, George Orwell, Max Weber, Stephen Hawking, Hans Staden e Zygmunt Bauman estarão no sambódromo este ano. Eles são alguns dos autores citados pelos carnavalescos como referências de seus enredos. No caderno destinado aos jurados do desfile, todas as escolas devem apresentar a bibliografia do enredo e outras fontes usadas. Para o enredo sobre o dinheiro e felicidade, Alex de Souza, da Acadêmicos da Rocinha, consultou páginas de A história da riqueza do homem, de Leo Huberman, e A ética protestante e o espírito do capitalismo, de Max Weber" (VIANNA, 2006, p. C1).

18 Entrevista com ex-carnavalesco das escolas dos grupos de acesso. Rio de Janeiro, 2008.
Não é só porque é bacana, nem porque o negro merece. É principalmente porque é mais barato. Enredo afro é bem mais barato! - não que seja mais fácil, pra sair bem feito, todos dão trabalho. Mas você pode utilizar uma série de materiais opacos, sem brilho, fazer mais reciclagem, aproveitar muita coisa - eu já fiz um [enredo afro] com praticamente tudo doado, é mais fácil conseguir. Isso tem uma implicação no custo total do carnaval. É por isso que você vê essa proliferação de enredo-afro. Pra fazer um tema de realeza, de corte (tipo Rosa Magalhães), ou algo mais modernoso, tecnológico (tipo Renato Lage) tem que ter muito ouro e prata, que são materiais mais caros, mesmo sendo fantasia. São temas de escola rica. Por isso as pessoas evitam, principalmente nos grupos de acesso, por questão de economia. ${ }^{18}$

O discurso do carnavalesco relativiza o dado considerado "original" no discurso das pequenas escolas de samba. A constância da temática afro-brasileira pode ser vista também como restritiva, determinada pela falta de recursos. Alguns temas-enredo são considerados mais "caros" e, por isso, evitados por escolas pequenas e em dificuldades financeiras e crises administrativas; temas históricos que envolvem as classes dirigentes (realeza, aristocracia) e ficções científicas (futurismo, robotização, império das máquinas, etc.) são considerados proibitivos para tais escolas, por implicar gastos exorbitantes com materiais, em especial nos tons dourados e prateados, sempre mais caros. Por outro lado, outros enredos são considerados mais adequados para as pequenas escolas, como aqueles que homenageiam per- 
sonalidades da realidade próxima (e por isso da mesma origem social, cercada pela mesma realidade material, em que ouro e prata certamente não abundam) ou personagens históricos negros e mestiços, recuperados e relidos pela nova perspectiva histórica, ou ainda temas relativos a lugares, como bairros e situações populares.

Sendo assim, estabelece-se certa restrição e repetição temática, decerto não imposta, mas considerada vantajosa pelos produtores, tacitamente aceita e exercida sobre a escolha de temas adequados para as escolas dos grupos de acesso. E mais uma vez, a "originalidade" exigida pelo grupo especial no quesito enredo, fica em segundo plano, entre as escolas dos grupos de acesso, reforçando a distância e diferença entre eles.

\section{BIBLIOGRAFIA}

AESCRJ. Manual do julgador das escolas de samba dos grupos de acesso $A, B, C, D$ e E. Rio de Janeiro, 2003.

. Regulamento específico das escolas de samba do grupo E. Rio de Janeiro, 2005. . Manual do julgador, carnaval 2008, grupos C, D e E. Rio de Janeiro, 2008.

AUGRAS, Monique. O Brasil do samba-enredo. Rio de Janeiro: Fundação Getúlio Vargas, 1998.

ARAÚJO, Eugênio. Não deixa o samba morrer: um estudo histórico e antropológico sobre o carnaval de São Luís e a escola Favela do Samba. São Luís: Edufma, 2001.

Valorizando a batucada: um estudo sobre as escolas de samba cariocas dos Grupos de Acesso $C$, $D$ e E. Tese de doutorado apresentada ao Programa de Pós-Graduação em Artes Visuais, EBA/UFRJ, 2008.

Vida e morte das pequenas escolas de samba: uma aproximação histórica e antropológica das escolas dos grupos de acesso "C", " $D$ " e "E" do Rio de Janeiro. Textos escolhidos de cultura e arte populares, Rio de Janeiro, v.6, n.1, p. 51-66, 2009.

BOURDIEU, P. O poder simbólico. Rio de Janeiro: Civilização Brasileira, 1995. . As regras da arte. São Paulo: Companhia das Letras, 1996.

BOTTOMORE, T. B. As elites e a sociedade. Rio de Janeiro: Zahar, 1974.

CAVALCANTI, Maria Laura Viveiros de Castro. O rito e o tempo: ensaios sobre carnaval. Rio de Janeiro: Civilização Brasileira, 1999.

CUNHA JUNIOR, Milton Reis. Paraísos e infernos na poética do enredo escrito de Joãosinho Trinta. Dissertação de mestrado em Letras, UFRJ, 2006.

CUNHA, Maria Clementina Pereira. Ecos da folia: uma história social do carnaval carioca entre 1880 e 1920. São Paulo: Companhia da Letras, 2001.

DAMATTA, Roberto. Carnavais, malandros e heróis. Rio de Janeiro: Guanabara/Koogan, 1990.

ELIAS, Norbert. O processo civilizador: uma história dos costumes. Rio de Janeiro: Zahar, 1994.

FARIAS, Júlio César. O enredo de escola de samba. Rio de Janeiro: Litteris, 2007.

LIESA. Abre-Alas/Rio Carnaval, Rio de Janeiro, 2005.

RIOTUR. Memória do Carnaval. Rio de Janeiro: Oficina do Livro, 1991.

TRAMONTE, Cristina. O samba conquista passagem: as estratégias educativas das escolas de samba. Petrópolis: Vozes, 2001. 
TURNER, Brian. Status. Lisboa: Ed. Estampa, 1989.

VIANNA, Luiz Fernando. Weber e Orwell inspiram enredos do Rio. Folha de S. Paulo. São Paulo, 25.2.2006, p. C1.

Eugênio Araújo é Professor Assistente do Departamento de Artes da UFMA, mestre em História da Arte e doutor em Artes Visuais pelo PPGAV/EBA/UFRJ.

Artigo recebido em agosto de 2010 e aceito para publicação em agosto 2010. 